て，一定期間の保存は実施されていたが，保存量が少な

く，検査に支障をきたす恐れがあったことから，今後は， 当該施設に限らず，適正な検食の保存方法について，更
に周知に努める必要がある.

（北海道保健福祉部 引木 満）

\section{7. ドクニンジンによる食中毒}

平成 9 年 4 月, 札幌市においてドクニンジンによる食 中毒が相次いで 2 件発生した.

〈事件例 1〉

\section{1) 事件の概要}

発生年月日 平成 9 年 4 月 16 日(水)

発生場 所 札幌市西区

摄食者数 2 名

患者数 1 名

死亡者数 0 名

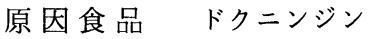

病因物質 植物性自然毒（コニイン）

原因施設家庭

\section{2）食中毒発生の探知}

平成 9 年 4 月 17 日午前 8 時 45 分，市内の男性加ら 「山菜のシャクを譲り受けた知人 2 名がおひたしにして 喫食したところ，1名が食中毒様の症状を呈している.」 と，札棍市保健所に通報があった。

\section{3）患者の発生状況及び症状}

平成 9 年 4 月 15 日, 患者の次女からもらい受けた一 握り強のシャクを翌 16 日午後 5 時 40 分, 全量をおひ たしにし，夫婦で喫食したところ，妻が同日午後 6 時か ら目まい, 動悸, 頭痛, 歩行困難, 手足の痺れなどの神 経麻痺症状を呈したため, 午後 8 時救急車で病院に運ば れた.

病院で，次女が持参した当該品の中にドクニンジンが 混入していることが確認され, 患者は点滴による処置を 受け, 症状は軽快し帰宅した.

\section{4)原因食品}

当該品は, 4 月 13 日に次女の知人が, 石狩市花川で採 取したシャクを翌 14 日にもらい，その一部を親夫婦に 譲渡したもので, 次女宅にあった残品を 4 月 17 日北海 道立衛生研究所に鑑定を依頼したところ，患者が契食し た植物はドクニンジンであることが確認されたこと, 更 に患者の症状がドクニンジンによる食中毒症状と一致し ていることから，原因食品はドクニンジンであると判定 した.

\section{〈事件例 2〉}

\section{1) 事件の概要}

発生年月日 発生場所 平成 9 年 4 月 29 日(火)

摂食者数 2 名 患者 数 1 名
死亡者数 0 名

原因食品・ドクニンジン

病因物 質 植物性自然毒（コニイン）

原因施設家庭

\section{2）食中毒発生の探知}

平成 9 年 4 月 30 日午前 8 時, 市内の男性から「行商 人からシャクを購入し，抽たしにして䒜食したとこ ろ, 妻が食中毒様の症状を呈した.」と, 札幌市保健所に 通報があった。

\section{3）患者の発生状況及び症状}

平成 9 年 4 月 29 日, 患者の夫が購入した山菜三把 （約 $300 \mathrm{~g}$ ）のシャクを全量をおひたしにし，同日午後 9 時 40 分，夫婦で㸷食した。

夫はわずかに食べただけだが，妻はほぼ一把分喫食し たところ, 妻が午後 10 時から目まい, 手足の痺れ，歩行 困難, 嘔吐などの神経麻痺症状を呈したため, 午後 10 時 30 分救急車で病院に運ばれた。

病院では，山菜による食中毒の疑いと診断され，患者 は安定剂を処方され帰宅したが，午後 11 時 30 分及び 午前 0 時の 2 回自分で䒜食物を吐き出したところ, 症状 は軽快した。

\section{4) 原因食品}

山菜の残品について 4 月 30 日，北海道立衛生研究所 に鑑定を依頼したところ，シャクではなくドクニンジン であることが確認されたこと, 更に患者の症状がドクニ ンジンによる食中毒症状と一致していることから, 原因 食品はドクニンジンであると判定した.

5) 考察及びまとめ

(1) この 2 つの事件は, ドクニンジンをシャクと間違 えて喫食したために発生した食中毒であり, 本市におい て初めて確認された事例である.

(2) ドクニンジンは植物性自然毒であるアルカロイ ドのコニインを全草に含んでおり, 毒性は非常に強力で あり, 少量を喫食しただけで運動神経麻痺, 呼吸麻痺の 症状を惹き起こし，死に至らしめる場合あある。

(3) ドクニンジンはヨーロッパが原産で, 葉は重複葉 で羽状に分裂した小葉からなり，ニンジンに似ている. 我が国では医薬品研究用にのみ植栽されていたあのであ るが，本市の一部地域で，野生化し自生していることが 確認されたことから, 今回, 一般市民への注意の呼びか けを報道機関を通じて行った。

(4) 近年, 自然指向の高まりから，山菜採りをする市 民が増えており，採取された植物の中には，食べられる かどうか区別の難しいものがあるため，保健所への鑑別 
相談も増加している.

これらのことから，今後とも，市民に対し有毒植物に
関する知識の普及, 啓発に努め, 食中毒の再発防止を図 りたい。

（札幌市保健福祉局 宮原誠一）

\section{8. トリカブトによる食中毒}

\section{1) 事件の概要}

$\begin{array}{ll}\text { 発生年月日 } & \text { 平成 } 9 \text { 年 } 4 \text { 月 } 27 \text { 日 (日) } \\ \text { 発生 場 所 } & \text { 秋田県北秋田郡田代町 } \\ \text { 攝 食 者 数 } & 3 \text { 名 } \\ \text { 患 者 数 } & 3 \text { 名 } \\ \text { 死 亡者数 } & 0 \text { 名 } \\ \text { 原 因食品 } & \text { トリカブト（オクトリカブト） } \\ \text { 病 因物 質 } & \text { アコニチン } \\ \text { 原因施 設 } & \text { 家庭 } \\ \text { 2) 事件の探知 }\end{array}$

平成 9 年 4 月 28 日, 午前 9 時 10 分, 大館市内の総 合病院から，「トリカブトが原因と思われる食中毒症状 で入院した患者がいる．残品のおひたしがあるので鑑定 してほしい.」との連絡が大館保健所にあった.
3) 発生の状況

4 月 27 日, 午後 0 時 30 分頃, 田代町の岩瀬ダム周辺 の沢で渓流釣りをしていた男性が，山菜 1 束（10 本程 度）を採取した，それを，午後 6 時頃，男性の妻がおひ

表 1. 症状別発症率

\begin{tabular}{lc}
\hline \hline \multicolumn{1}{c}{ 症 状 } & 発 症 率 $(\%)$ \\
\hline 口唇, 舌のしびれ & 100 \\
手足のしびれ & 66.7 \\
脱力感 & 66.7 \\
嘔吐 & 66.7 \\
不整脈 & 66.7 \\
下痢 & 33.3 \\
めまい & 33.3 \\
そ尿 & 33.3 \\
呼吸困難 & 33.3
\end{tabular}
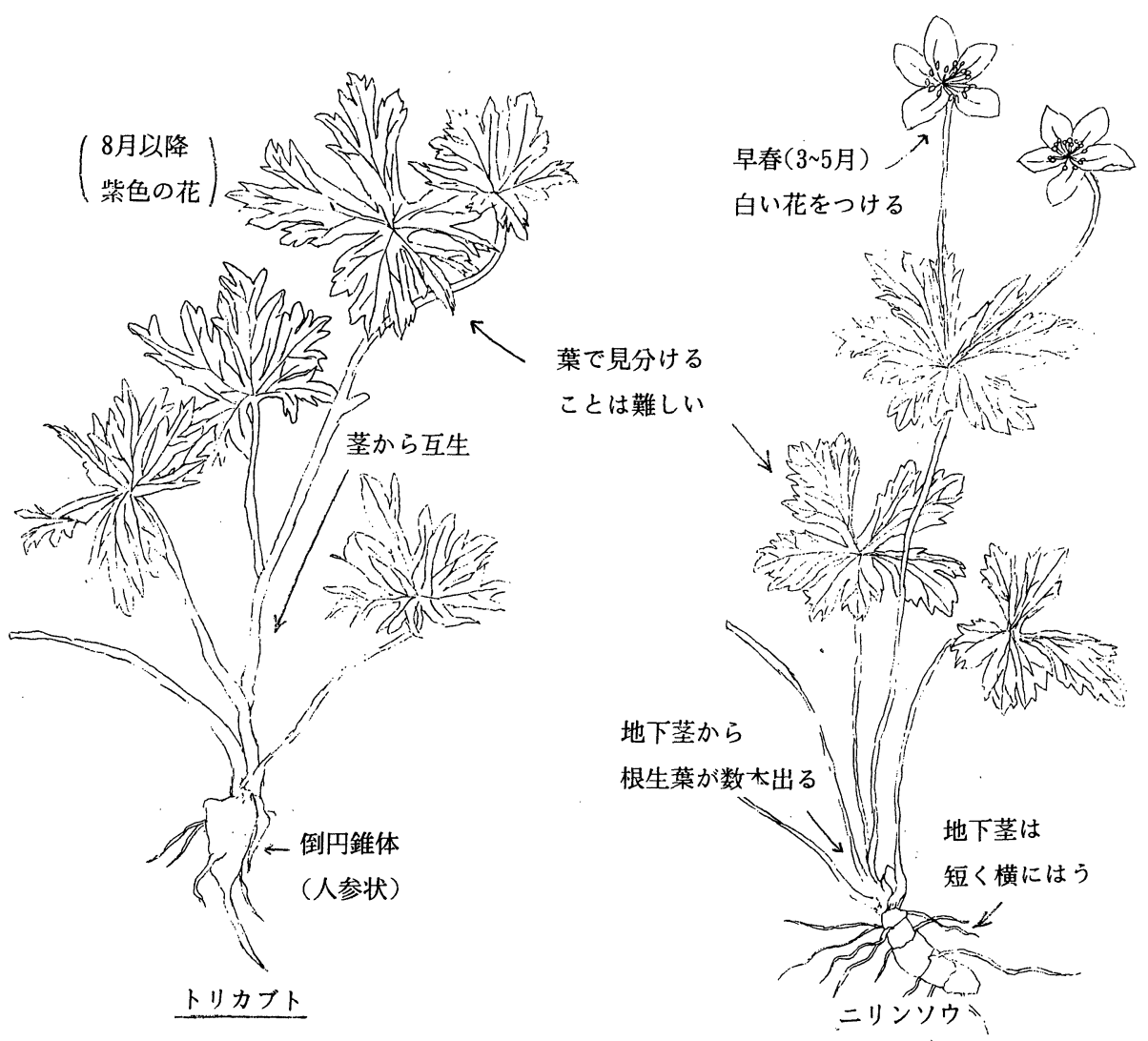

図 1.トリカブトとニリンソウの違い 